\title{
Cost Analysis of Clinical Compounding in Saudi Arabia: Anti-tuberculosis Pediatrics Formulations
}

\begin{abstract}
Yousef Ahmed Alomi* (D), General Administration of Pharmaceutical Care, Ministry of Health, Riyadh, Saudi Arabia.

Faiz A. Bahadig, Informatics Pharmacist, Pharmaceutical Care Department, King Abdul-Aziz Medical, City-WRJeddah, Ministry of National Guard, Saudi Arabia.

Malika Alhadab, Head, Pharmacy Services, Alyamma Hopsital, Ministry of Health, Riyadh, Saudi Arabia.

Mona Lubbad, Former Head, Extemporaneous Preparation Unit, Pharmacy services, Alyamma Hopsital, Ministry of Health, Riyadh, Saudi Arabia.

Ebtesam Nazal, Head, Extem poraneous Preparation Unit, Pharmacy Services, Alyamma Hopsital, Ministry of Health, Riyadh, Saudi Arabia.

Mayssa Ahmed Assiri, Clinical Pharmacy Staff, General Manager of General Administration of Pharmaceutical Care, Ministry of Health, Riyadh, Saudi Arabia.
\end{abstract}

\section{Correspondence:}

Dr. Yousef Ahmed Alomi, The Former General Manager of General Administration of Pharmaceutical Care, Former Head, National Clinical pharmacy and pharmacy practice, Former Head, Pharmacy R\&D Administration, Ministry of Health, P.O.BOX 100, Riyadh-11392, Saudi Arabia.

Phone no: +966 504417712

E-mail:yalomi@gmail.com

Received: 12-01-2019;

Accepted: 07-05-2019

Copyright: @ the author(s), publisher and licensee International Journal of Pharmacology and Clinical Sciences. This is an open-access article distributed under the terms of the Creative Commons Attribution Non-Commercial License, which permits unrestricted non-commercial use, distribution, and reproduction in any medium, provided the original work is properly cited.

This is an open access article distributed under the terms of the Creative Commons Attribution-NonCommercial-ShareAlike 4.0 License

Access this article online

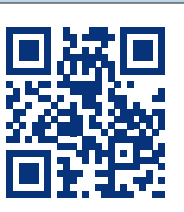

www.ijpcs.net

DOI:

10.5530/ijpcs.2019.8.35

\begin{abstract}
Objectives: In this study, we explored the cost analysis of selected pediatric antituberculosis formulations available at the pharmacy of a pediatrics and maternity hospital in Riyadh city, Saudi Arabia. Methods: This is a retrospective cost analysis study of pediatric anti-tuberculosis formulations conducted at a pediatrics and maternity hospital having 300 beds in Riyadh city, Saudi Arabia. The pharmacy section of this hospital receives the specific formulation from the physician. Then the expert pharmacist provides the clinical compounding services to healthcare staff and patients over $8 \mathrm{hr}$ per day for 5 days per a week. The pediatric formulations consisted of selected anti-tuberculosis medications. The cost analysis included variable expenses such as personal cost, material cost and supply cost. Fixed costs included direct cost, nonsalary cost and overhead cost. All costs were derived from the Ministry of Health information database. All costs were analyzed in terms of US dollar currency by using the Microsoft Excel software version 10. Results: The estimated average total standard cost of pediatric anti-tuberculosis formulations per hour was 53.82 USD, which included 58.58\% (31.53 USD) personal cost, 25.14\% (13.53 USD) overhead cost, 3.34\% (1.8 USD) material and supply cost and $12.93 \%$ (6.96 USD) non-salary cost. The average estimated cost of rifampicin per preparation was 11.36 USD. The total annual cost of rifampicin was 1363.20 USD. The average estimated cost of pyrazinamide per preparation was 6.835 USD. The total annual cost of pyrazinamide was 68.35 USD. The average estimated cost of isoniazid per preparation was 8.515 USD. The total annual cost of isoniazid was 85.15 USD. Conclusion: Two anti-tuberculosis pediatric formulations (rifampicin and isoniazid) were available for various prices, whereas pyrazinamide was not available as pediatric formulation either locally or in USA and UK. The pharmacist should prepare all anti-tuberculosis pediatric formulation when needed. The cost analysis of all anti-tuberculosis pediatric formulations should be determined in order to meet health insurance and the strategies of New Saudi Vision 2030 in the Kingdom of Saudi Arabia.

Key words: Cost, Clinical compounding, Anti-tuberculosis, Pediatric formulations,
\end{abstract} Ministry of Health, Saudi Arabia.

\section{INTRODUCTION}

Tuberculosis is one of the most commonly found tropical diseases in some developed countries. ${ }^{[1]}$ It is distributed in several African, South American and in Middle Eastern population. Beside the Tuberculosis distributed in the Europe countries and the USA especially with Human Immunodeficiency Virus (HIV) patients. In Saudi Arabia, it is restricted to some pediatric, geriatric and HIV populations. The WHO has estimated that in 2017, an estimated 1 million children were affected with tuberculosis and around 233,000 children died due to it (including children with HIV-associated tuberculosis). ${ }^{[1]}$ The prevalence of tuberculosis in children in Saudi Arabia has reached up to $2 \%-14 \%$ with an incidence rate of 2 per $100,000 .{ }^{[2]}$ The updated management guidelines recommend the need to treat the patients with at least four medications during the first 2 months and then continue with two medications for the next 6 months. ${ }^{[3]}$ The anti-tuberculosis medication with first- or second-line management of resistance case were listed in the $\mathrm{MOH}$ drug formulary. ${ }^{[4]}$ All medications were dispensed free of cost to all Saudi citizens or to visitors during the Hajj period. The medications were in the oral dosage form and two were intravenous medications. The oral medications were in tablet or capsule form. The pediatric formulations of ant tuberculosis were not commonly manufactured and all forms were not available. Four essential medications of pediatric formulations are needed to be available 24/7 at the $\mathrm{MOH}$ healthcare institution. Moreover, the pharmacy strategic plan with New Saudi Vision 2030 recommended establishing the cost analysis of medications project as part of health and Pharmacoeconomical goal of the plan. ${ }^{[5]}$ The cost analysis is required to calculate the cost income or expenses with net cost budget. All prices of anti-tuberculosis medications with adults dosage form were listed by Saudi Food and Drug Authority (SFDA) in Saudi Arabia. However, some pediatric anti-tuberculosis medications had no cost mentioned on it. To the best of our knowledge, there are no studies about the cost analysis of pediatric formulations of some anti-tuberculosis medications. ${ }^{[6]}$ There- 
fore, in this study, we aimed to conduct the cost analysis of pediatric formulations of some antituberculosis medications in the KSA.

\section{METHODS}

This is a retrospective cost analysis study related to the anti-tuberculosis pediatric formulations available in the previous year at a pediatrics and maternity hospital in Riyadh city, Saudi Arabia. It had inpatient admission, ambulatory care clinics and emergency departments and has 300 beds. The hospital had a different specialty for women and pediatrics. The hospital provides the services to the common neonatal, pediatrics and women health disease. The pharmacy section of the hospital provides services such as unit dose drug distribution system, outpatient pharmacy and extensive extemporaneous pediatric section and drug information center. The pharmacy computerized physician order entry with an electronic prescription in addition to the pharmacy had medications safety program. The pharmacy conducts clinical and pharmacy training programs for students. The extemporaneous section had very comprehensive pediatrics formulations for neonates and pediatrics in the central region of $\mathrm{MOH}$ hospitals. The section received the specific formulation from physician then the expert pharmacist applied the international standard of clinical compounding through of providing to healthcare staff over $8 \mathrm{hr}$ per days for 5 days per a week. The pediatrics formulations consisted of antibiotics, anti-tuberculosis medications, anticonvulsant medications, Gastrointestinal (GI) drugs, anti-hypertension medications, electrolyte supplements, renal preparations, diuretics formulations, steroid preparations and other supportive substances formulation. The cost analysis included variable expenses such as personal cost, material and supply cost and fixed costs included direct cost, non-salary cost and overhead cost. ${ }^{[7,8]}$ In addition to the cost of compounding, number of preparations and time needed for preparations were also analyzed. The price derived from the $\mathrm{MOH}$ information database. All cost used US dollar currency. The study analyzed anti-tuberculosis pediatric formulations by using Microsoft Excel software version 10 .

\section{RESULTS}

The estimated average total standard cost of pediatric formulations per hour was 53.82 USD and consisted of $58.58 \%$ (31.53 USD) personal cost, $25.14 \%$ (13.53 USD) overhead cost, $3.34 \%$ (1.8 USD) material and supply cost and $12.93 \%$ (6.96 USD) non-salary cost (Table 1). The average estimated cost of rifampicin per preparation was 11.36 USD which consisted of standard cost (0.33 USD) and direct cost (11.03
USD). The total annual cost of rifampicin was 1363.20 USD (Table 2). The average estimated cost of pyrazinamide per preparation was 6.835 USD which consisted of standard cost (4.36 USD) and direct cost (2.47 USD). The total annual cost of pyrazinamide was 68.35 USD (Table 3 ). The average estimated cost of isoniazid per preparation was 8.515 USD which consisted of standard cost (4.36 USD) and direct cost (4.15 USD). The total annual cost of isoniazid was 85.15 USD (Table 4).

\section{DISCUSSION}

The updated management of tuberculosis in pediatrics recommends treatment with four medications for the first 2 months and then continue with two medications for the next 4 months. All four medications mostly were available as oral tablets or as capsules. ${ }^{[9-12]}$ Two medications (Isoniazid and Rifampicin) were available as syrup or suspension and intravenous administration..$^{[9-12]}$ The other two medications (Ethambutol or Pyrazinamide) were not available as syrup or suspension for pediatric use or for neonates ingestion. ${ }^{[9-12]}$ Therefore, the extemporaneous preparation of all antituberculosis medications at pharmacy unit is highly recommended unless available in the local market. The cost analysis of extemporaneous pediatric formulations is a part to determine the annual budget. This study was conducted to solve this problem. The cost analysis of four anti-tuberculosis pediatric formulations is divided into two parts: indirect and direct cost. The indirect cost includes personal cost, overhead cost, material cost and non-salary cost were almost equal for four preparations. However, the total cost in the pharmacy budget differed according to the number of preparations annually. The majority of the indirect cost came from personal cost, which was followed by the overhead cost. This is excepted because the majority of the preparations needed pharmacist and/or pharmacy technicians to prepare the pediatric formulations with less of overhead cost demand for preparation. The findings showed that the rifampicin formulations were more expensive than formulation registered in the UK, which maybe the direct cost in the extemporaneous type was higher the than manufactures. ${ }^{[11,12]}$ Our analysis showed that pyrazinamide is not registered at local or USA and UK (Table 5) and the majority of the total cost came from indirect cost because the number of preparations was a low number. ${ }^{[9-12]}$ The findings showed that the cost of INH direct cost almost equalized to the indirect cost because the number of preparations were few annually. The cost of INH was more expensive than manufactures' cost in the US market. ${ }^{[10]}$ This is because of the high cost of production
Table 1: Standard cost analysis of pediatrics formulations (USD).

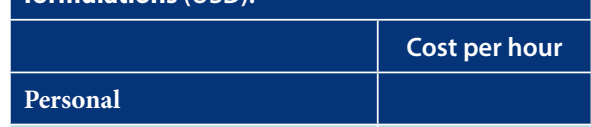

Head compounding pharmacist 27.27

staff compounding pharmacist 4.26

Total

31.53

Over Head cost

Rent 0

Bed 0

\begin{tabular}{l|l}
\hline Offices & 0.46 \\
\hline
\end{tabular}

\begin{tabular}{|l|l|}
\hline Chairs & 1.54 \\
\hline
\end{tabular}

\begin{tabular}{l|l} 
Computer & 0.68
\end{tabular}

\begin{tabular}{l|l} 
Printer & 1.43 \\
\hline
\end{tabular}

\begin{tabular}{|l|l|} 
Zebra label printer (Direct & 3.08 \\
\hline
\end{tabular}

Thermal)

\begin{tabular}{l|l|l} 
Refrigerator & 1.66
\end{tabular}

\begin{tabular}{|l|l|}
\hline Balance & 0.17 \\
\hline
\end{tabular}

\begin{tabular}{|l|l}
\hline Beakers & 0.14 \\
\hline
\end{tabular}

\begin{tabular}{|l|l}
\hline Stainless steel spoon & 0.21
\end{tabular}

\begin{tabular}{l|l}
\hline Measuring cup & 0.25 \\
\hline
\end{tabular}

\begin{tabular}{|l|l}
\hline Measuring Cylinder & 0.15 \\
\hline
\end{tabular}

\begin{tabular}{l|l}
\hline Silicone spoon & 0.05 \\
\hline
\end{tabular}

\begin{tabular}{|l|r|}
\hline Cooker & 0.03 \\
\hline
\end{tabular}

\begin{tabular}{|l|l}
\hline Funnel & 0.04 \\
\hline
\end{tabular}

\begin{tabular}{|l|r|}
\hline Bunchner & 0.05 \\
\hline
\end{tabular}

\begin{tabular}{|l|l|}
\hline Test tube brush & 0.04 \\
\hline
\end{tabular}

\begin{tabular}{l|l} 
Kettle & 0.15
\end{tabular}

\begin{tabular}{|l|l} 
Mortar and Pestle & 0.11 \\
\hline
\end{tabular}

\begin{tabular}{l|l} 
Glass rode & 0.02 \\
\hline
\end{tabular}

\begin{tabular}{|l|l|}
\hline Shelf & 3.23 \\
\hline
\end{tabular}

\begin{tabular}{|l|l}
\hline Pen/pencils & 0.04
\end{tabular}

\begin{tabular}{l|l} 
Scissors & 0.02
\end{tabular}

\begin{tabular}{l|l} 
Total & 13.53
\end{tabular}

Material and supply

\begin{tabular}{l|l} 
Large & 0.65 \\
\hline
\end{tabular}

\begin{tabular}{l|l} 
Amber bottle & 0.21
\end{tabular}

\begin{tabular}{|l|l|}
\hline Syringe & 0.12
\end{tabular}

\begin{tabular}{l|r} 
Gloves & 0.49
\end{tabular}

\begin{tabular}{|l|l|}
\hline Blue sheet & 0.31 \\
\hline
\end{tabular}

\begin{tabular}{l|l} 
Face mask & 0.02 \\
\hline
\end{tabular}

\begin{tabular}{|l|l|}
\hline Total & 1.8 \\
\hline
\end{tabular}

\section{Non Salary cost}

Education and Training head

Education and Training staff

Total

6.96 
Table 2: Cost of Rifampicin 25 mg/mL (USD).

\begin{tabular}{|c|c|}
\hline Personal & 31.53 \\
\hline Over Head cost & 13.53 \\
\hline Material and supply & 1.8 \\
\hline Non Salary cost & 6.96 \\
\hline Total & 53.82 \\
\hline Preparation time 45 min per one bottle & 40.365 \\
\hline Total of preparation 120 per year, the cost per one $100 \mathrm{ml}$ & 0.33 \\
\hline \multicolumn{2}{|l|}{ Direct cost } \\
\hline Rifampicin 300mg = 10 Cap & 9.97 \\
\hline M.S.V. to $100 \mathrm{ml}$ & 1.06 \\
\hline Total & 11.03 \\
\hline Grand Total $100 \mathrm{ml}$ per bottle & 11.36 \\
\hline Annual Grand Total cost & $1,363.20$ \\
\hline \multicolumn{2}{|l|}{ References } \\
\hline \multicolumn{2}{|c|}{$\begin{array}{l}\text { 1. V.AllenLY,EricksonMA.Stabilityofbethanecholchloride, pyrazinamide, quin- } \\
\text { idine sulfate, rifampin and tetracycline hydrochloride in extemporaneously } \\
\text { compounded oral liquids. Am J Health-Syst Pharm. 1998; 155: 1804-1809 }\end{array}$} \\
\hline
\end{tabular}

\begin{tabular}{|l|c|}
\hline Table 4: Cost of Isoniazid $\mathbf{1 0} \mathbf{~ m g / m L ~ ( U S D ) . ~}$ & 31.53 \\
\hline Personal & 13.53 \\
\hline Over Head cost & 1.8 \\
\hline Material and supply & 6.96 \\
\hline Non Salary cost & 53.82 \\
\hline Total & 40.365 \\
\hline Preparation time 45 min per one bottle & 4.365 \\
\hline $\begin{array}{l}\text { Total of preparation when needed per year ( around 10), the cost } \\
\text { per one 120 ml }\end{array}$ & \\
\hline \begin{tabular}{l} 
Direct cost \\
\hline Isoniazid 100mg tab = 10 tablets
\end{tabular} & 0.48 \\
\hline Sorbitol 70\% = 85.7 ml & 3.66 \\
\hline \begin{tabular}{l} 
dist. Water = 34.3 ml \\
\hline Total
\end{tabular} & 0.01 \\
\hline \begin{tabular}{l} 
Grand Total 120 ml per bottle \\
\hline Annual Grand Total cost
\end{tabular} & 8.15 \\
\hline $\begin{array}{l}\text { References } \\
\text { 1. Nahata MC, Hipple TF, Pediatric Drug Formulations, Cincinnati, Ohio: Har- } \\
\text { vey Whitney Books Company;1992. }\end{array}$ \\
\hline $\begin{array}{l}\text { 2. M. Haq ABS, Mohd Din RB, Othman NB, et al. Extemporaneous Formula- } \\
\text { tion. Pharmaceutical Services Division. Ministry of Health Malaysia. } 2015 .\end{array}$ \\
\hline
\end{tabular}

Table 3: Cost of Pyrazinamide $10 \mathrm{mg} / \mathrm{mL}$ (USD).

\begin{tabular}{|c|c|}
\hline Personal & 31.53 \\
\hline Over Head cost & 13.53 \\
\hline Material and supply & 1.8 \\
\hline Non Salary cost & 6.96 \\
\hline Total & 53.82 \\
\hline Preparation time $45 \mathrm{~min}$ per one bottle & 40.365 \\
\hline $\begin{array}{l}\text { Total of preparation when needed per } \\
\text { year (around 10), the cost per one } 200 \\
\mathrm{ml}\end{array}$ & 4.365 \\
\hline Direct cost & \\
\hline Pyrazinamide $500 \mathrm{mg}=4$ tablets & 0.71 \\
\hline universal vehicle to $200 \mathrm{ml}$ & 1.76 \\
\hline Total & 2.47 \\
\hline Grand Total $200 \mathrm{ml}$ per bottle & 6.835 \\
\hline Annual Grand Total cost & 68.35 \\
\hline \multicolumn{2}{|l|}{ References } \\
\hline \multicolumn{2}{|c|}{$\begin{array}{l}\text { 1. V. Allen LY, Erickson MA. Stability of } \\
\text { bethanechol chloride, pyrazinamide, quinidine } \\
\text { sulfate, rifampin and tetracycline hydrochloride } \\
\text { in extemporaneously compounded oral liquids. } \\
\text { Am J Health-Syst Pharm. 1998; 155: 1804-1809 }\end{array}$} \\
\hline $\begin{array}{l}\text { 2. M. Haq ABS, Mohd Din RB, Othman } \\
\text { Extemporaneous Formulation. Pharn } \\
\text { Services Division. Ministry of Health } \\
2015\end{array}$ & $\begin{array}{l}\mathrm{JB} \text {, et al. } \\
\text { aceutical } \\
\text { Malaysia. }\end{array}$ \\
\hline
\end{tabular}

of preparation in the pharmaceutical industry with lower cost margin as compared to hospital pharmacies. The majority of the budget of anti-tuberculosis pediatric formulations came from rifampicin and low with INH and pyrazinamide, which is related to the high number of preparation of the rifampicin products. This is the first study to be conducted in the KSA with regard to cost of pediatric formulations of some anti-tuberculosis medications. The cost analysis of all anti-tuberculosis pediatric formulations is highly recommended to meet the pharmacy strategic plan with New Saudi Vision 2030. ${ }^{[13]}$

\section{CONCLUSION}

Tuberculosis is one of the most common diseases of the developing countries, including Saudi Arabia. Most of the oral medications for adults or adolescents with different dosage forms are available in the local and international market. However, most of the anti-tuberculosis pediatric formulation is seldom found. The extemporaneous preparation of pediatric formulation of anti-tuberculosis medications, including cost analysis is an essential requirement of pharmacy strategic plan and New Saudi Vision 2030. The cost analysis of pediatric anti-tuberculosis medications is recommended to be conducted regularly in the KSA.

\section{ACKNOWLEDGEMENT}

None.

\section{CONFLICT OF INTEREST}

The authors declare no conflict of interest.

\section{ABBREVIATIONS}

HIV: Human Immunodeficiency Virus; SFDA: Saudi Food and Drug Authority; WHO: World Health Organization; KSA: Kingdom of Saudi Arabia; USD: United State Dollars; GI: gastrointestinal; GERD: Gastroesophageal reflex diseases, MOH: Ministry of Health; TB: tuberculosis; USA: United States of America; UK: United Kingdom.

\section{ORCID ID}

Yousef Ahmed Alomi org/0000-0003-1381-628X

https://orcid.

\section{REFERENCES}

World Health Organisation. Global Health TB Report. 2018.

2. AlJahdali HH, Baharoon $\mathrm{S}, \mathrm{Abba} A \mathrm{~A}$, Memish ZA, Alrajhi AA, Albarrak A, et al. Saudi guidelines for testing and treatment of latent tuberculosis infection. Ann Saudi Med. 2010;30(1):38-49.

3. World Health Organization. The use of delamanid in the treatment of multidrug-resistant tuberculosis in children and adolescents. 2016;48.

4. Ministry of Health. Ministry of Health Formulary. 2012. MOH Saudi Arabia.

5. Alomi YA, Alghamdi SJ, Alattyh RA, Elshenawy RA. The Evaluation of Pharmacy Strategic Plan in Past 2013-2016 and Forecasting of New Vision 2030 at Ministry of Health in Saudi Arabia. J Pharm Pract Community Med. 2018;4(2):93-101.

6. Günther G, Gomez GB, Lange C, Rupert S, Leth FV. Availability, price and affordability of anti-tu- 


\begin{tabular}{|c|c|c|c|c|c|c|c|c|}
\hline \multirow{2}{*}{$\begin{array}{l}\text { Medications } \\
\text { name }\end{array}$} & \multicolumn{2}{|c|}{ Cost Current study } & \multicolumn{2}{|c|}{ Cost in SA (USD) ${ }^{[11]}$} & \multicolumn{2}{|c|}{ Cost in US (USD) ${ }^{[12]}$} & \multicolumn{2}{|c|}{ Cost in UK (USD) $)^{[13,9]}$} \\
\hline & $\begin{array}{l}\text { Conc. } \\
\mathrm{mg} / \mathrm{ml}\end{array}$ & Volume & $\begin{array}{l}\text { Conc. } \\
\mathrm{mg} / \mathrm{ml}\end{array}$ & Volume & $\begin{array}{l}\text { Conc. } \\
\mathrm{mg} / \mathrm{ml}\end{array}$ & Volume & $\begin{array}{l}\text { Conc. } \\
\mathrm{mg} / \mathrm{ml}\end{array}$ & Volume \\
\hline $\begin{array}{l}\text { Rifampicin } \\
25 \mathrm{mg} / 1 \mathrm{ml}\end{array}$ & $1 \mathrm{mg} / \mathrm{ml}=0.00454 \$$ & $100 \mathrm{ml}=11.36 \$$ & $\begin{array}{c}\text { Not } \\
\text { available }\end{array}$ & Not available & $\begin{array}{c}\text { Not } \\
\text { available }\end{array}$ & Not available & $\begin{array}{l}1 \mathrm{mg} / \mathrm{ml}= \\
0.00224 \$\end{array}$ & $\begin{array}{c}20 \mathrm{mg} / \mathrm{ml} \\
120 \mathrm{ml}=5.38 \$ \\
(100 \mathrm{ml}=4.483 \$)\end{array}$ \\
\hline $\begin{array}{l}\text { Pyrazinamide } \\
10 \mathrm{mg} / 1 \mathrm{ml}\end{array}$ & $1 \mathrm{mg} / \mathrm{ml}=0.00342 \$$ & $\begin{array}{c}200 \mathrm{ml}=6.835 \$ \\
(100 \mathrm{ml}=3.419 \$)\end{array}$ & $\begin{array}{c}\text { Not } \\
\text { available }\end{array}$ & Not available & $\begin{array}{c}\text { Not } \\
\text { available }\end{array}$ & Not available & Non available & Non available \\
\hline $\begin{array}{l}\text { Isoniazid } \\
10 \mathrm{mg} / 1 \mathrm{ml}\end{array}$ & $1 \mathrm{mg} / \mathrm{ml}=0.0071 \$$ & $\begin{array}{c}120 \mathrm{ml}=8.515 \$ \\
(100 \mathrm{ml}=7.095 \$)\end{array}$ & $\begin{array}{c}\text { Not } \\
\text { available }\end{array}$ & Not available & $\begin{array}{c}1 \mathrm{mg} / \mathrm{ml}= \\
0.0694 \$\end{array}$ & $\begin{array}{c}10 \mathrm{mg} / \mathrm{ml} \\
600 \mathrm{ml}=416.99 \$ \\
(100 \mathrm{ml}=69.49 \$)\end{array}$ & Non available & Non available \\
\hline
\end{tabular}

berculosis drugs in Europe: A TBNET survey. Eur Respir J. 2015;45(4):1081-8.

7. Alomi YA, Al-Jarallah SM. The Cost Analysis of Network Drug Information Services at Ministry of Health Institutions in Saudi Arabia. J Pharm Pract

Community Med. 2018;4(4):226-30.

8. Alomi YA, Alsulami N, AlQahtani N, Mashouf M Qahtani A, Almansor FA. Cost Analysis of Drug Information Services at the Mental Hospital in
Saudi Arabia. J Pharm Pract Community Med. 2018;4(2):83-6

9. British Medical Association. BNF: For Children. 20172018

10. Saudi Food and Drug Authority. List of human medicine and herbal health. 2019. [cited 2019 Jun 17]. Available from: https://www.sfda.gov.sa/en/ drug/resources/Pages/DrugsUnderRegistrations. aspx

11. Athenahealth. Epocrates Online. Epocrates.com.
2017 [cited 2019 Jun 17]. Available from: https:// online.epocrates.com/home

12. Ah-See KW, et al. Royal Pharmaceutical Society. British National Formulary 76. British National Formulary. BMJ Group. 2019;1-1653.

13. Alomi YA. New Pharmacy Model for Vision 2030 in Saudi Arabia. J Pharm Pract Community Med. 2017;3(3):194-6. 